\title{
STUDIES ON VARIETAL DIVERSITY AND SELECTION OF POTENTIAL VARIETIES OF GERBERA (GERBERA JAMESONII H. BOLUS EX HOOK. F.) FOR COMMERCIAL CULTIVATION IN BANGLADESH
}

\author{
Rabina Islam*, Nazmul Alam and Mohammed Kamal Hossain \\ Department of Botany, Jahangirnagar University, Savar, Dhaka, Bangladesh
}

Keywords: Gerbera, Varietal diversity, $\mathrm{D}^{2}$ statistics

\begin{abstract}
Ten commercial genotypes of Gerbera jamesonii were evaluated for a number of qualitative and quantitative traits in RCBD at the Botanical Garden of Jahangirnagar University, Savar, Dhaka. Qualitative morphology among 10 genotypes showed significant similarities and dissimilarities. The analysis of variance for all the quantitative traits showed highly significant variations among the genotypes. Genotypes Dutch Diva, Classic Fabio Gold, Candela and Dune proved to be the most suitable and sustainable as they were the best performer for different growth and flower quality parameters. Number of flowers per plant found best in Candela and Dutch Diva (11.33). The phenotypic coefficients of variation (PCV) were found higher than the genotypic coefficients of variation (GCV) for all characters. Maximum GCV and PCV were observed for number of suckers per plant (30.984 and 39.568) followed by number of whorls of ray florets per flower and days to flowering from bud initiation. High heritability values were obtained for all the characters. In high heritability estimate coupled with high genetic advance as percentage of mean was maximum for days to first flowering (32.442), plant height (cm) (17.026) and number of suckers per plant (15.992). Selection would be effective for the character showing high performance in genetic parameter. Path analysis revealed that the diameter of disc florets per flower, stalk girth $(\mathrm{cm})$, number of disc florets per flower, number of ray florets per flower would be selection criteria for improvement in flower number. Based on $\mathrm{D}^{2}$ statistics, 10 genotypes were grouped into 3 clusters, namely cluster I, II and III. Highest number of genotypes was found in cluster I containing 5 genotypes. Scatter diagram represents pattern of genotypic distribution into clustering through principal component scores. Highest inter-cluster distance (22.94) was observed between cluster I and III. The genotypes of cluster II possessed heterogeneous nature and showed highest intra-cluster distance (11.35). Highest cluster mean was observed in cluster II containing four genotypes regarded as the superior than another cluster.
\end{abstract}

\section{Introduction}

Gerbera jamesonii an ornamental plant belonging to Asteraceae is very popular and widely used as its cut flowers are used in making bouquets and for various decorative purposes (Nair et al. 2003). Gerbera is one of the ten most popular commercial cut flowers grown throughout the world (Pattanashetti et al. 2012) scattered from Africa to Madagascar (Khosa et al. 2011) into tropical Asia and South America (Tjia and Joiner 1984). It ranks fourth in the international cut flower market and is a popular cut flower in Holland, Germany and USA (Choudhary and Prasad 2000).

Due to the increasing demands of flower in local and international market, floriculture has become very popular in recent years especially in the urban areas. Because of a wide variety of colours and shapes, Gerbera (Gerbera jamesonii L.) is regarded as the latest sensation to commercial cultivation. To meet up the local demand, many nurseries started to propagate Gerbera through cutting. Along with nursery cultivation, tissue culture approach might be a prospective alternative for mass propagation of Gerbera. As the economy of Bangladesh is largely

*Author for correspondence: <rabina.ju.shh@gmail.com> 
dependent on agriculture, this flowering plant can have a great contribution to the economic growth as well as for opening a new dimension in the field of agriculture in Bangladesh.

Thus present investigation were undertaken to select the proper variety for achieving the goal of production of high yield and better quality of flowers suitable for domestic and international markets.

\section{Materials and Methods}

The experimental material for the present study comprised of ten diverse genotypes of Gerbera namely Winter Queen, Swanlake, Candela, Ruby Red, Captiva, Classic Fabio Gold, Dune, Long beach, Dutch Diva and Pre-Intense collected from different local nurseries in Dhaka, Bangladesh. The genotypes were evaluated through a field experiment conducted in a Randomized Complete Block Design (RCBD) with three replications at the Botanical Garden of Jahangirnagar University during late Rabi season (September-December) in 2018. The soil of the experimental field was sandy loam in texture. The experimental field was divided into three blocks. Each block was then sub-divided into ten plots. The unit plot size was $90 \times 60 \times 60 \mathrm{~cm}$. Block to block distance was $30 \mathrm{~cm}$. Genotypes were randomly assigned in different blocks. The fertilizer and manure were applied as per recommended dose for the commercial cultivation of Gerbera and the intercultural practices were followed when required. Biometric data were recorded on ten randomly selected plants from each genotype in each replication for quantitative traits namely plant height $(\mathrm{cm})$, days to first flowering, days to flowering from bud initiation, number of suckers per plant, stalk length $(\mathrm{cm})$, stalk girth $(\mathrm{cm})$, flower diameter $(\mathrm{cm})$, neck diameter $(\mathrm{cm})$, number of petals per flower, diameter of disc florets/flower $(\mathrm{cm})$, number of disc florets per flower, number of ray florets per flowers, number of whorls of ray florets/flower, flower longevity (days), number of flowers per plant and vase life of cut flowers (days).

The collected data were compiled and tabulated in proper forms for statistical analysis. Analysis of variance was performed with the help of a MSTAT-C program (Freed 1986). To test the differences between genotypes, Duncan's Multiple Range Test (DMRT) was performed according to the method of (Steel and Torrie 1960). The variance components namely genotypic coefficient of variation (GCV), phenotypic coefficient of variation (PCV), broad sense heritability and genetic advance were determined following Kumar et al. (1985).

The genetic divergence among the germplasms was assessed following Mahalanobis $\mathrm{D}^{2}$ statistics (Mahalanobis 1936). The Mahalanobis distance $\left(\mathrm{D}^{2}\right)$ values were calculated from transformed uncorrelated means of characters according to Singh and Chaudhary (1979). Mean data for each character were subjected to multivariate Principal Component Analysis (PCA), Principal Coordinate Analysis (PCO), Cluster Analysis (CLSA) and Canonical Variate Analysis (CVA) using GENSTAT 5.5 (Mahalanobis 1936, Digby et al. 1989). Scattered diagram obtained for first three principal component scores were done by R 3.0.2 software.

\section{Results and Discussion}

The mean performance of genotypes gives an overall view of performance of genotypes. Highest number of flowers per plant was recorded 11.33 by Candela and Dutch Diva followed by Classic Fabio-Gold (11), Dune (10.67). Highest flower longevity was recorded as 22.33 days in Ruby Red followed by Captiva (22 days), Swanlake (21.33 days). Highest vase life was recorded by Dutch Diva (14.33) followed by Pre-Intense (14), Winter Queen (13.67). Highest number of petals per flower was recorded as 60.66 in Long Beach followed by Classic Fabio-Gold (60.33), 58.67 in Captiva, Swanlake and Winter Queen. Dutch Diva has the largest sized flower $(13.66 \mathrm{~cm})$ 
whereas the flower length $(\mathrm{cm})$ was highest in Long Beach $(61.06 \mathrm{~cm})$. Lowest number of flowers per plant was recorded in Winter Queen (8.67).

So, the most suitable and sustainable genotypes are Dutch Diva, Classic Fabio-Gold, Candela and Dune as they were best performer for different growth and flower quality parameters. Genotypes of Winter Queen, Pre-Intense, Captiva and Ruby Red were poor performer in respect to number of flowers per plant and its related characters. Rests of the genotypes were moderate performer.

The widest range of variation was recorded by days to first flowering (32 - 57), followed by number of ray florets per flower (54 - 78), number of disc florets per flower (56 - 78), number of petals per flower (45 - 64), stalk length (46.3 - 63.2), plant height (30 - 42.5) and flower longevity (16 - 25), whereas narrowest range was observed for stalk girth $(0.6-1.1)$ and diameter of disc florets per flower $(2.1-2.8)$ and neck diameter $(0.8-2)$.

When the number of samples was increased to estimate the mean value, the standard error was decreased. Lowest value of standard error indicates the mean value is close to the population mean. Here highest standard error observed for number of ray florets per flower followed by number of petals per flower, number of disc, stalk length $(\mathrm{cm})$ and standard error of other character is comparatively lower. Here the mean value for number of ray florets per flower followed by number of petals per flower, number of disc, stalk length $(\mathrm{cm})$ was not exactly equal to the population mean. And the mean value for other characters is close to the population mean. F-test is significant at $1 \%$ for all character among genotypes.

Coefficient of variation (CV\%) does not have any unit. It is a measure of variability in a sample and is useful in comparison of variability for a character among genotypes. If the coefficient of variation is less than 1 indicates low variance, the value is more than 1 indicates high variance. In the present study all of the characters represent high variance. Number of suckers per plant and number of whorls of ray florets per flower are responsible for highest variation among the genotypes. The higher the $\mathrm{CV} \%$, the more variable the data within a study (Table 1).

Results presented in Table 2 revealed that all the characters studied exhibited higher PCV than GCV. A higher value for PCV than GCV is an indication of environmental influence on expression of that particular character. Nair and Shiva (2003), Kolte (2008), Chobe et al. (2010), Kumari et al. (2011) reported similar results in gerbera and Misra and Salini (1990) and Jhon et al. (2002) in gladiolus. Highest GCV and PCV were noticed for number of suckers per plant followed by number of whorls of ray florets per flower and days to flowering from bud initiation. Chobe et al. (2010) also obtained high GCV and PCV for number of suckers per plant in gerbera. This indicated that in this flower crop, selection for number of suckers per plant can be done on the basis of phenotypic performance.

Difference between phenotypic and genotypic coefficients of variation was highest for number of suckers per plant and number of whorls of ray florets per flower. Number of days for first flowering, plant height $(\mathrm{cm})$, number of disc florets per flower and stalk length $(\mathrm{cm})$ showed very low difference. Therefore, the variation observed among these characters might be due to genetic makeup of varieties and less influence of environment.

A high estimate of heritability indicates a relatively low contribution of the environmental factors to the phenotypic variance, while a low heritability estimates show a high contribution of the environment. Selection would be more effective for the character having high heritability than for those exhibiting low heritability. Most of the studied characters are highly heritable in this study which is in line with the results observed by Patra and Mohanti (2014) in gladiolus, Senapati et al. (2013) in gerbera. The highest heritability was recorded for days to first flowering, plant height $(\mathrm{cm})$, stalk length $(\mathrm{cm})$, no. of disc florets per flower, days to flowering from bud initiation. 


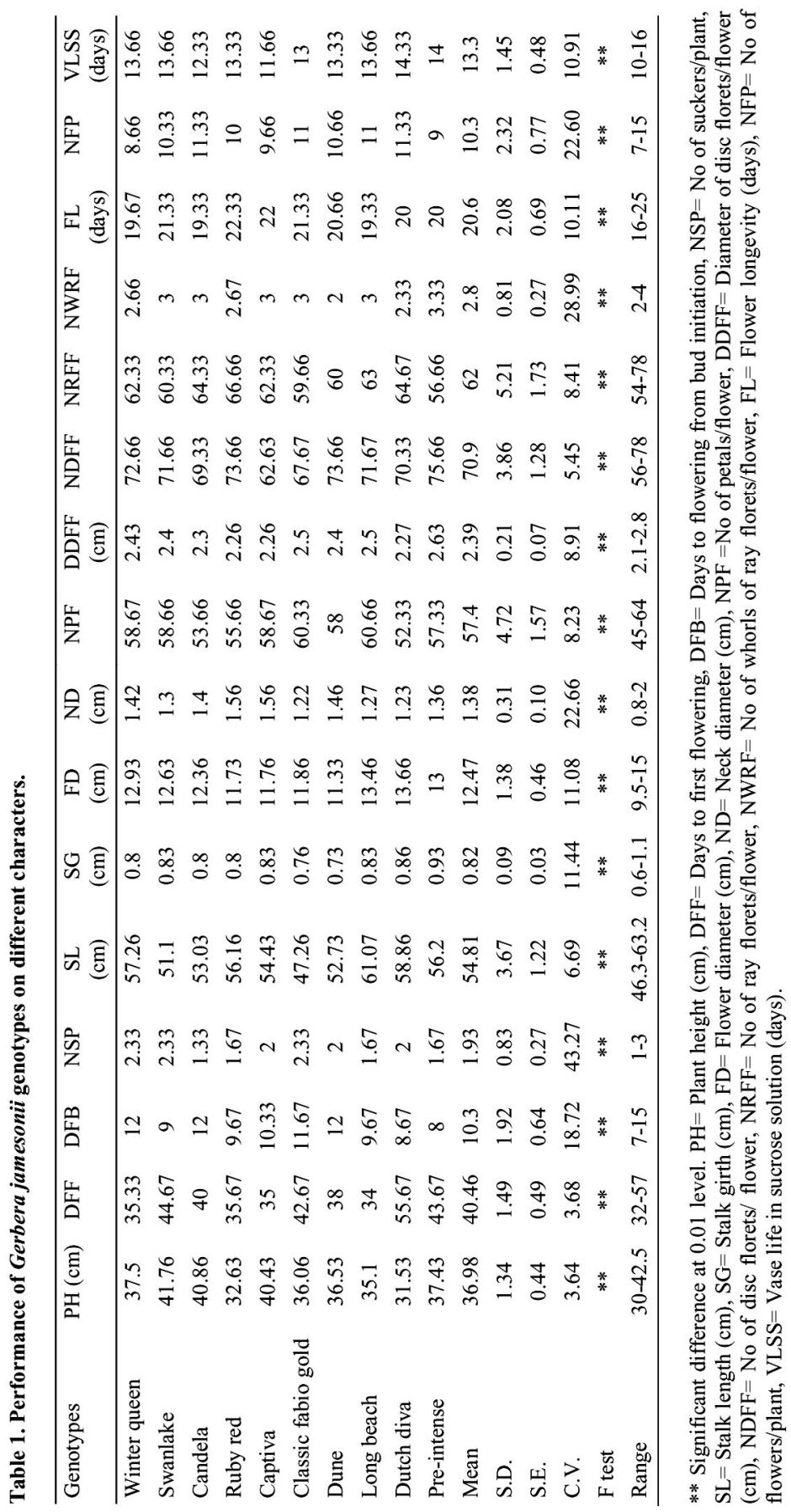


This finding is in consonance with the findings reported by Warner and Walworth (2009) in Petunia (Namita et al. 2008) in French marigold. Such high heritability estimates have been found to be helpful in making selection of superior genotypes on the basis of phenotypic performance for quantitative traits.

High heritability coupled with high genetic advance was observed for days to first flowering, plant height $(\mathrm{cm})$, stalk length $(\mathrm{cm})$ and number of disc florets/flower which suggested that the selection among the genotypes can bring about significant improvement for these characters (Table 2). This is in conformity with the findings of Kumar (2015) and Mishra et al. (2006) in Chrysanthemum and Jhon et al. (1994) in Zinnia. In general, the characters which exhibit high heritability with high genetic advance are significantly controlled by additive genes (Panse and Sukhatme 1967) and can be improved through mass selection, progeny selection or any other modified selection procedures. The qualitative trait had high heritability and high genetic advance, which confirms the predominance of additive gene action. And the trait exhibited low amount of heritability and genetic advance which indicated the presence of non-additive gene action that include dominance and epistasis for these traits and thus, improvement of these traits by selection was not possible.

Table 2. Estimation of genotypic coefficient of variation (GCV), phenotypic coefficient of variation (PCV), heritability in broad sense as percentage $\left(h^{2}\right)$, genetic advancement at $5 \%(\mathrm{GA} 5 \%)$, genetic advancement as percentage of mean $1 \%$ (GA 1\%).

\begin{tabular}{lccccc}
\hline Characters & GCV & PCV & $\begin{array}{c}\mathrm{h}^{2} \text { (Broad } \\
\text { sense) } \%\end{array}$ & $\begin{array}{c}\text { Genetic } \\
\text { advancement 5\% }\end{array}$ & $\begin{array}{c}\text { Genetic adv. As \% } \\
\text { of mean 5\% }\end{array}$ \\
\hline Plant height(cm) & 8.926 & 9.641 & 85.734 & 6.297 & 17.026 \\
Days to first flowering & 16.151 & 16.566 & 95.063 & 13.128 & 32.442 \\
$\begin{array}{l}\text { Days to flowering from } \\
\text { bud initiation }\end{array}$ & 10.148 & 21.295 & 22.709 & 1.026 & 9.962 \\
No. of suckers/plant & 30.984 & 39.568 & 19.620 & 0.309 & 15.992 \\
Stalk length(cm) & 6.179 & 9.113 & 45.978 & 4.731 & 8.631 \\
Stalk girth(cm) & 1.049 & 11.498 & 0.8333 & 0.002 & 0.197 \\
Flower diameter(cm) & 0.65 & 11.058 & 0.516 & 0.015 & 0.117 \\
Neck diameter(cm) & 0.63 & 20.631 & 20.213 & 0.118 & 8.591 \\
No. of petals/flower & 0.184 & 8.233 & 0.049 & 0.005 & 0.008 \\
Diameter of disc florets/ & 0.622 & 8.931 & 0.485 & 0.0021 & 0.089 \\
flower (cm) & & & & & 5.206 \\
No. of disc florets/flower & 4.165 & 6.863 & 36.822 & 3.691 & 0.375 \\
No. of ray florets/flower & 1.728 & 8.314 & 2.188 & 0.232 & 6.371 \\
No. of whorls of ray & 2.95 & 27.493 & 11.25 & 0.178 & 1.189 \\
florets/flower & & & & & 8.541 \\
Flower longevity(days) & 0.08 & 9.825 & 5.877 & 0.245 & 0.805 \\
No. of flowers/plant & 2.306 & 20.629 & 20.098 & 0.879 & \\
Vase life in sucrose & 17.67 & 10.721 & 3.643 & 0.107 & \\
solution(days) & & & & & \\
\hline
\end{tabular}

Evaluation of genetic diversity in available germplasms is important for execution of different breeding programme for further improvement. The success of breeding programme depends to a large extent on the degree of genetic divergence. Genetic diversity is the key factor for crop improvement and of paramount important for heterosis. Hybridization between genetically 
divergent hybrid parents is expected to produce superior hybrids and desirable recombinants. Mahalanobis $\mathrm{D}^{2}$ statistics appears to be faithful approach which is based on multivariate analysis and serves to be a good index of genetic diversity.

The main aim of clustering of genotypes was selection as well as rejection of genotypes for further breeding program. By the application of non-hierarchical clustering based on sixteen quantitative characters, 10 genotypes were grouped into three distinct clusters (Table 3). These results confirmed the clustering pattern of the genotypes according to principle component analysis. Highest number of genotypes was found in cluster I containing 5 genotypes followed by cluster II containing four genotypes and clusters III containing only one genotype. Ando et al. (2005) found 4 cluster comprising of 113 genotypes by using 21 morphological characters in Petunia, Swaroop (2010) grouped 28 Gladiolus genotypes into 8 clusters using 13 similar characters, Patra and Mohanti (2014) grouped 30 genotypes into 12 clusters and Bharati et al. (2014) grouped 28 genotypes into five cluster in African marigold.

Table 3. Distribution of ten genotypes of Gerbera jamesonii in different cluster by Tocher Method based on $D^{2}$ statistic.

\begin{tabular}{ccl}
\hline Cluster & No. of genotypes & Genotype name \\
\hline I & 5 & Winter Queen, Ruby Red, Captiva, Dune and Long Beach \\
II & 4 & Swanlake, Candela, Classic Fabio-Gold and Pre Intense \\
III & 1 & Dutch Diva \\
\hline
\end{tabular}

The cluster means for different characters (Table 4) indicated considerable difference among the clusters. The genotypes of cluster II produced highest mean for number of disc florets/flower, number of ray florets/flower, number of petals/flower, stalk length, days to first flowering, plant height and moderate mean for flower longevity (days), vase life in sucrose solution (days), flower diameter $(\mathrm{cm})$, number of flowers/plant, days to flowering from bud initiation regarded as the superior than other cluster. The genotypes of cluster I produced highest mean number of disc florets/flower, number of ray florets/flower, number of petals/flower, stalk length and moderate mean for plant height, days to first flowering, flower longevity (days), vase life in sucrose solution (days), flower diameter $(\mathrm{cm})$, days to flowering from bud initiation, number of flowers/plant can also be regarded as superior cluster. Another superior cluster III which produced highest mean for number of disc florets/flower and moderate mean for flower longevity (days), vase life in sucrose solution (days), flower diameter $(\mathrm{cm})$, number of flowers/plant, days to flowering from bud initiation.

The principal component analysis yielded Eigen values of each principal component axes of coordination of genotypes with the first axes totally accounted for the variation among the genotypes (Table 5). Pattern of distribution of genotypes in the scattered diagram revealed that considerable variability existed in the concerned genotypes.

A three dimensional scatter diagram were done by using first three principal axes PCA 1, PCA 2 and PCA 3 accounted for $62.9 \%$ of the total variation among the genotypes. The scatter diagram represents the pattern of distribution of genotypes resembled considerable variability excised among the genotypes (Fig. 1). Here first 3 axes are accounted to represent variation among the genotypes in the scatter diagram because of highest Eigen value and per cent contribution of these axes. PCA were used to represent clustering pattern among the genotypes (Fig. 1).

Highest intra cluster distance was observed between the genotypes of cluster II indicating that genotypes included in this cluster are very diverse (Table 6). Lowest intra cluster distance was 
observed between the genotypes of cluster III representing the homogenous nature of the genotypes. The intra-cluster distance in all the three clusters were lower than the inter-cluster distances suggesting wider diversity among genotypes of the distant groups except the genetic distance between cluster II and cluster III.

Table 4. Cluster mean for various characters in Gerbera jamesonii genotypes.

\begin{tabular}{lccc}
\hline \multirow{1}{*}{\multicolumn{1}{c}{ Characters }} & \multicolumn{3}{c}{ Clusters } \\
\cline { 2 - 4 } & I & II & III \\
\hline Plant height(cm) & 36.44 & 39.03 & 31.53 \\
Days to first flowering & 35.6 & 42.75 & 55.67 \\
Days to flowering from bud initiation & 10.73 & 10.17 & 8.67 \\
No of suckers/plant & 1.93 & 1.92 & 2 \\
Stalk length(cm) & 56.33 & 51.9 & 58.87 \\
Stalk girth(cm) & 0.8 & 0.83 & 0.87 \\
Flower diameter(cm) & 12.25 & 12.47 & 13.67 \\
Neck diameter(cm) & 1.45 & 1.32 & 1.23 \\
No of petals/flower & 58.33 & 57.5 & 52.33 \\
Diameter of disc florets/flower & 2.37 & 2.45 & 2.27 \\
No of disc florets/flower & 70.87 & 71.08 & 70.33 \\
No of ray florets/flower & 62.86 & 60.25 & 64.67 \\
No of whorls of ray florets/flower & 2.67 & 3.08 & 2.33 \\
Flower longevity(days) & 20.8 & 20.5 & 20 \\
No of flowers/plant & 10 & 10.42 & 11.33 \\
Vase life in sucrose solution(days) & 13.13 & 13.25 & 14.33 \\
\hline
\end{tabular}

Table 5. Eigen values and percentage of variation for corresponding 16 principle components in ten genotypes of Gerbera jamesonii.

\begin{tabular}{ccccc}
\hline Sl.No. & $\begin{array}{c}\text { No. of principle component } \\
\text { axes (PCA) }\end{array}$ & $\begin{array}{c}\text { Eigen } \\
\text { values }\end{array}$ & $\begin{array}{c}\text { Percentage of } \\
\text { variance }(\%)\end{array}$ & $\begin{array}{c}\text { Cumulative percentage } \\
\text { of variance }(\%)\end{array}$ \\
\hline 1 & PCA 1 & 4.603579 & 28.77 & 28.77 \\
2 & PCA 2 & 3.250595 & 20.32 & 49.09 \\
3 & PCA 3 & 2.209778 & 13.81 & 62.89 \\
4 & PCA 4 & 1.875155 & 11.71 & 74.62 \\
5 & PCA 5 & 1.571784 & 9.82 & 84.44 \\
6 & PCA 6 & 1.019386 & 6.37 & 90.81 \\
7 & PCA 7 & 0.806981 & 5.04 & 95.85 \\
8 & PCA 8 & 0.359857 & 2.25 & 98.11 \\
9 & PCA 9 & 0.302886 & 1.89 & 100 \\
\hline
\end{tabular}

Inter cluster distance and cluster means important for flower number contributing characters were simultaneously considered to select hybrid parents for further improvement. Highest inter cluster distance was observed in between cluster I and cluster III followed by cluster II and cluster III indicating that heterogeneous nature of germplasm among these clusters (Table 6) (Fig. 1). 
Lowest inter cluster distance observed in cluster II and cluster I indicate that homogenous nature of germplasms lines within the cluster. This is indicative of the fact that the genotypes included in these cluster have greater genetic divergence and hence intermating between the genotypes belonging to that would give more transgressive segregates in advance generations.

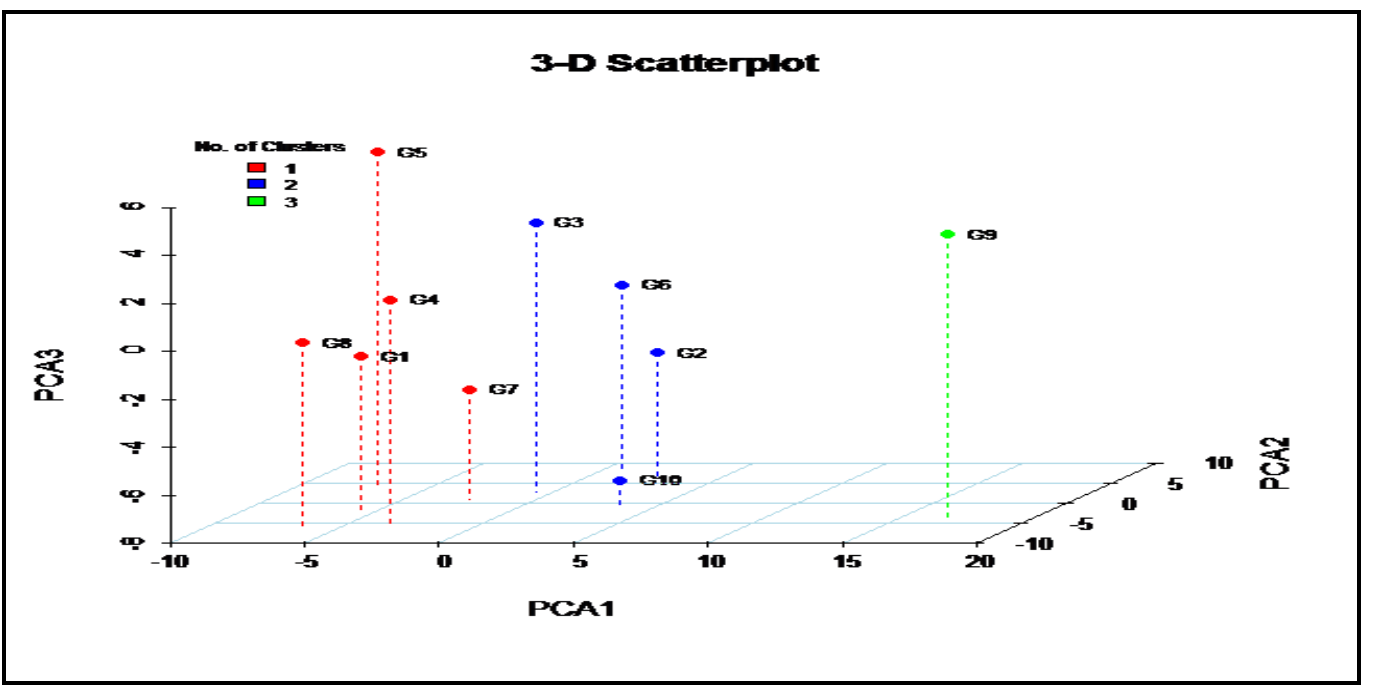

Fig. 1. Distribution of different genotypes in a 3D plot (scattered diagram) based on PCA scores.

G1 = Winter Queen, G2 = Swanlake, G3 = Candela, G4 = Ruby Red, G5 = Captiva, G6 = Classic Fabio Gold, G7 = Dune, G8 = Long Beach, G9 = Dutch Diva, G10 = Pre Intense.

Table 6. Average Intra (bold) and Inter cluster distance for Gerbera jamesonii genotypes.

\begin{tabular}{cccc}
\hline Cluster & I & II & III \\
I & $\mathbf{1 0 . 3 4 6 7 2}$ & 13.0859 & 22.93742 \\
II & - & $\mathbf{1 1 . 0 0 3 5 6}$ & 19.24447 \\
III & - & - & $\mathbf{0}$ \\
\hline
\end{tabular}

The cluster means for different characters (Table 4) indicated considerable difference among the clusters. The genotypes of cluster II produced highest mean for number of disc florets/flower, number of ray florets/flower, number of petals/flower, stalk length, days to first flowering, plant height and moderate mean for flower longevity (days), vase life in sucrose solution (days), flower diameter $(\mathrm{cm})$, number of flowers/plant, days to flowering from bud initiation regarded as the superior than other cluster. The genotypes of cluster I produced highest mean number of disc florets/flower, number of ray florets/flower, number of petals/flower, stalk length and moderate mean for plant height, days to first flowering, flower longevity (days), vase life in sucrose solution (days), flower diameter $(\mathrm{cm})$, days to flowering from bud initiation, number of flowers/plant can also be regarded as superior cluster. Another superior cluster III which produced highest mean for number of disc florets/flower and moderate mean for flower longevity (days), vase life in sucrose solution (days), flower diameter $(\mathrm{cm})$, number of flowers/plant, days to flowering from bud initiation. 
It can be concluded from high cluster mean for most of the yield contributing traits that the genotypes of cluster II and cluster I are the most suitable and sustainable in respect to number of flower/plant attributing traits.

\section{References}

Ando T, Ishikawa N, Watanabe H, Kokubun H, Yanagisawa Y, Shimoto G, Marchesi E and Suarez E 2005. A morphological study of the Petunia integrifolia complex (Solanaceae). Ann. Bot. 96: 887-900.

Bharathi TU, Jawaharlal M, Kannan M, Manivannan N and Raveendran M 2014. Correlation and path analysis in African Marigold (Tagetes erecta L.). The Bioscan 9(4): 1673-1676.

Chobe RR, Pachankar PB and Warade SD 2010. Studies on genetic variability and heritability in gerbera. Asian J. Hort. 5 (2): 356-358.

Choudhary ML and Prasad KV 2000. Protected cultivation of ornamental crops an insight. Indian Hort. 45(1): 31-37.

Digby P, Galway N and Lane P 1989. Genstat.5: A Second Course. Oxford Sci. Publication, Oxford. pp: 103108.

Freed R 1986. MSTAT-C program, 384C Plant and Soil Sciences. Michigan State University, East Lansing, MI. Int. J. Pl. Breed. 7(1): 42-49.

Jhon AQ, Paul TM and Neelofar M 1994. Genetic variability and correlation studies in Zinnia (Zinnia elegans Jacq.). J. Orn. Hort. 21(1-2): 1-4.

Jhon AQ, Bichoo GA and Wani SA 2002. Correlation studies in gladiolus. J. Ornam. Hort. 5(1): 25-29.

Khosa SS, Adnan Y, Adnan R, Shahina Y and Atif R 2011.Effect of foliar application of macro and micronutrients on growth and flowering of Gerbera jamesonii L. American-Eurasian J. Agricul. Environ. Sci. 11(5): 736-757.

Kolte SL 2008. Studies on genetic diversity in gerbera (Gerbera jamesonii). M.Sc. (Ag.) Thesis, Mahatma Phule Krishi Vidyapeeth, Rahuri, Ahmednagar (M.S.).

Kumar A, Misra SC, Singh YP and Chauhan BPS 1985. Variability and correlation studies in Triticale. J. Maharashtra Agric. Univ. 10: 273-275.

Kumar S, Malik S, Kumar M and Singh O 2015. Variability, heritability and genetic advance in chrysenthemum (Dendranthema grandiflora Tzvelev). Prog Hort. 47(2): 271-274.

Kumari A, Patel KS and Choudhary M 2011. Genetic variability studies in gerbera. Res. Plant Biol. 1: 1-4.

Mahalanobis PC 1936. On the generalized distance in statistics. Proce. Nat. Inst. Sci. 2(1): 49-55.

Misra RL and Saini HC 1990. Correlation and path coefficient studies in gladiolus. Indian J. Hort. 47(1): 127-132.

Mishra HN, Das JN and Palai SK 2006. Character association and path coefficient analysis in spray type chrysenthemum. Orissa J. Hort. 34(2): 32-33.

Nair SA and Shiva KN 2003. Genetic variability, correlation and path coefficient analysis in gerbera. J. Orn. Hort. 6(3): 180-187.

Nair SA, Singh V and Sharma TVRS 2003. Effect of chemical preservatives on enhancing vase-life of gerbera flowers. J. Tropical Agri. 41: 56-58.

Namita, Singh KP, Raju DVS, Prasad KV and Bharadwaj C 2008. Studies on genetic variability, heritability and genetic advance in French marigold (Tagets patula) genotypes. J. Orn. Hort. 12(1): 30-34.

Panse VC and Sukhatme PV 1967. Statistical Methods for Agriculture Workers. Indian Council of Agricultural Research, New Delhi. pp: 152-161.

Patra SK and Mohanty CR 2014. Variability studies in gladilous. Asian J. Hort. 9(2): 352-355.

Pattanashetti CN, Athani SI, Harish DK and Imamsaheb SJ 2012. Economics of gerbera (Gerbera jamesonii) cultivation under protected conditions. Plant Archives 12(1): 91-94.

Senapati AK, Prajapati P and Singh A 2013.Genetic variability and heritability studies in Gerbera jamesonii Bolus. Afr. J. Agric. Res. 8(41): 5090-5092. 
Singh PK and Chaudhary BD 1979. Biometrical methods in quantitative genetic analysis. Kalyani Publishers. New Delhi, India. pp: 210-214.

Steel RGD and Torrie JH 1960. Principles and procedures of statistics. Mcgraw Hill Book Co. Inc. New York. pp. 107-110.

Swaroop K 2010. Morphological variation and evaluation of gladiolus germplasm. Indian J Agr. Sci. 80(8): 742-745.

Tjia B and Joiner JN 1984. Growing gerberas. Greenhouse Manager. 3(6): 67-75.

Warner RM and Walworth AE 2009. Quantitative inheritance of crop timing traits in interspecific hybrid Petunia populations and interactions with crop quality parameters. J. Hered. 101(3): 308-316.

(Manuscript received on 17 September, 2019; revised on 22 October, 2020) 